\title{
Seasonal changes in the pineal gland related to the reproductive cycle in the male hare, Lepus europaeus
}

\author{
G. A. Lincoln \\ M.R.C. Unit of Reproductive Biology, 2 Forrest Road, Edinburgh EH1 2QW, U.K.
}

Summary. During the autumn months, the gonads and reproductive tract of adult male hares (Lepus europaeus) are regressed and circulating gonadotrophin levels are low. At this time the pineal glands are most active as judged by the organ size, and the nuclear and cytoplasmic size of the pinealocytes. There was an inverse relationship between the size of the pineal gland and the weight of the testis, the plasma and testicular testosterone levels, and possibly also the plasma LH levels.

Many clinical and experimental observations suggest a functional link between the pineal gland and the gonads of mammals (see Wurtman, Axelrod \& Kelly, 1968). Antigonadotrophic factors have been found in the pineal glands of several species and the organ probably modifies the activity of the gonads by influencing the secretion of gonadotrophins from the pituitary by its action on the hypothalamus (Fraschini, Collu \& Martini, 1971; Vaughan, Reiter, Vaughan, Bigelow \& Altschule, 1972).

The suppressive effect of the pineal gland on reproduction is of particular interest in seasonally breeding animals in which there are conspicuous changes in the reproductive tract during the year and the pineal appears to play some role in mediating the environmental effect of light on reproduction (Herbert, 1972; Reiter, 1973). Histological studies of wild animals indicate that the pineal gland may be most active when the gonads are regressed (Mogler, 1958; Quay, 1956; Millar, 1972; Pevet \& Saboureau, 1973). The purpose of the present study was to extend these observations to the brown hare, Lepus europaeus, which experiences seasonal regression of the gonads and reproductive tract (Lincoln, 1974).

Thirty-four adult male hares estimated to be $>12$ months of age were shot during 1971 on arable land near Guestwich in Norfolk $\left(52^{\circ} 48 \mathrm{~N}, 0^{\circ} 59^{\prime} \mathrm{E}\right)$ for a separate study (Lincoln, 1974). At the time of death a blood sample was taken and stored on ice until the plasma could be separated 1-4 hr later. The left testis was placed on solid $\mathrm{CO}_{2}$ and later weighed, and the posterior portion of the skull, including the brain tissue surrounding the intact pineal gland, was fixed in formol saline.

Plasma LH levels were measured by radioimmunoassay as described by Lincoln \& MacKinnon (1976), and the testosterone levels in the testes and plasma were measured by the radioimmunoassay of Rowe et al. (1974), with a single chromatographic separation for the testicular tissue (Lincoln, 1974). The fixed pineal organs were dissected from the adjoining tissue, weighed, and paraffin-wax sections cut at $5 \mu \mathrm{m}$ and stained in haematoxylin and eosin. Nuclear diameters of 20 randomly selected pinealocytes were measured in each of 2 animals from each month, and the cytoplasmic extent of these cells assessed by counting the number of nuclei in 10 random high-power microscope fields for each animal. Correlation coefficients were calculated by least square analysis and the probabilities determined by Student's $t$ test.

There was a clearly defined seasonal cycle in all reproductive parameters measured. During the non-breeding season in September and October, LH values were low, the testes were small and blood and testicular testosterone levels were minimal (Table 1). The peak in reproductive activity occurred from March to June when the circulating levels of LH were high, the testes fully developed, and the blood and testicular levels of testosterone were maximal.

The weight of the pineal gland also varied throughout the year, being $71 \%$ larger in September and October than in May and June. The nucleus of the pinealocytes was increased in diameter, the nucleoli were more conspicuous, and the cytoplasm more expansive in the pineals of animals killed 
between June and October, compared to those of animals killed between December to April (Table 1). There was an inverse relationship between the weights of pineals and the weights of the testes $(r=-0.721 ; P<0.001)$, the testosterone content of the testes $(r=-0.526 ; P=<0.02)$ and the testosterone concentration of the blood $(r=-0.530 ; P=<0.02)$ of hares shot at the different seasons. There was also an inverse relationship between pineal weight and plasma LH level, although this was only significant $(P<0.05)$ if 3 animals with greatly elevated $\mathrm{LH}$ values $(>30 \mathrm{ng} / \mathrm{ml})$ were omitted. These high values were thought to be due to episodic LH secretion and not to reflect closely the mean circulating levels.

Table 1. Characteristics (mean \pm S.E.M.) of the pineal gland and reproductive tract of adult male hares killed at different times of year

\begin{tabular}{|c|c|c|c|c|c|c|}
\hline & Jan./Feb. & March/April & May/June & July/Aug. & Sep./Oct. & Nov./Dec. \\
\hline No. of animals & 5 & 4 & 7 & 8 & 5 & 5 \\
\hline Wt of left testis (g) & $9 \cdot 0 \pm 0.2$ & $9.7 \pm 0.7$ & $10 \cdot 3 \pm 0 \cdot 3$ & $7 \cdot 3 \pm 0 \cdot 8$ & $1 \cdot 7 \pm 0.1$ & $3.8 \pm 0.6$ \\
\hline Wt of seminal vesicles $(\mathrm{g})$ & $2 \cdot 1 \pm 0.1$ & $2 \cdot 6 \pm 0.2$ & $3 \cdot 1 \pm 0 \cdot 3$ & $2 \cdot 2 \pm 0 \cdot 2$ & $0.7 \pm 0.1$ & $0.9 \pm 0.2$ \\
\hline $\begin{array}{l}\text { Plasma LH (ng NIH-LH- } \\
\text { S13/ml) }\end{array}$ & $2.4 \pm 0.5$ & $3.7 \pm 0.4$ & $5.4 \pm 0.7^{*}$ & $2 \cdot 1 \pm 0 \cdot 4 \dagger$ & $1 \cdot 3 \pm 0 \cdot 1$ & $2 \cdot 0 \pm 0 \cdot 2$ \\
\hline Plasma testosterone $(\mathrm{ng} / 100 \mathrm{ml})$ & $151 \pm 23$ & $349 \pm 78$ & $414 \pm 54$ & $179 \pm 30$ & $74 \pm 20$ & $105 \pm 42$ \\
\hline $\begin{array}{l}\text { Testicular testosterone } \\
\text { (ng/testis) }\end{array}$ & $450 \pm 206$ & $914 \pm 130$ & $863 \pm 171$ & $220 \pm 45$ & $23 \pm 2$ & $75 \pm 7$ \\
\hline Pineal wt (mg) & $20 \cdot 8 \pm 0.8$ & $18 \cdot 3 \pm 1 \cdot 5$ & $16 \cdot 1 \pm 1 \cdot 9$ & $18 \cdot 3 \pm 4 \cdot 1$ & $27 \cdot 4 \pm 3 \cdot 5$ & $22 \cdot 8 \pm 2 \cdot 5$ \\
\hline $\begin{array}{l}\text { Diam. of pinealocyte nucleus } \\
(\mu \mathrm{m})\end{array}$ & $6.4 \pm 0.06$ & $6.4 \pm 0.06$ & $6.7 \pm 0.07$ & $6.5 \pm 0.5$ & $6.7 \pm 0.07$ & $6.2 \pm 0.04$ \\
\hline $\begin{array}{l}\text { No. of pinealocyte nuclei/ } \\
\text { high-power microscope field }\end{array}$ & $69 \pm 3$ & $62 \pm 2$ & $60 \pm 1$ & $58 \pm 2$ & $49 \pm 1$ & $58 \pm 3$ \\
\hline
\end{tabular}

Values for $* 2$ hares and $\div 1$ hare omitted (see text).

The present results are consistent with the premise that the pineal gland has a suppressive effect on the function of the reproductive system. An increase in the overall size of the pineal gland, and an increase in the nuclear volume and the staining reaction of the nucleolus, have been claimed to indicate enhanced pineal activity (Fiske, Bryant \& Putman, 1960; Roth et al., 1962), and there is therefore evidence that increased pineal activity is associated with decreased gonadal activity in the hare. Since photoperiod is thought to control the timing of the reproductive cycle in the hare (Lyman, 1943; Davis \& Meyer, 1972), it is probable that the pineal gland plays a role in mediating the daylength effect as described in the hamster (Reiter, 1973). Thus, changing daylength following the summer solstice in June leads to an increase in pineal activity, and the secretion of an unknown factor which suppresses gonadotrophin secretion and leads to gonadal regression. After October the reverse changes occur and with the removal of the suppressive effect of the pineal the male hare regains its fertility.

\section{References}

DAvis, G.J. \& MeYER, R.K. (1972) The effect of daylength on pituitary FSH and LH and gonadal development of snowshoe hares. Biol. Reprod. 6, 264-269.

Fraschini, F., Collu, R. \& Martini, L. (1971) Mechanisms of inhibitory action of pineal principles on gonadotrophin secretion. In The Pineal Gland, Ciba Fndn Symp. pp. 259-273. Eds G. E. W. Wolstenholme \& J. Knight. Churchill Livingstone, Edinburgh.

Fiske, V.M., Bryant, G.K. \& Putman, J. (1960) Effect of light on the weight of the pineal gland in the rat. Endocrinology 66, 187-196.

Herbert, J. (1972) Initial observations on pinealecto- mized ferrets kept for long periods in either daylight or artificial illumination. $J$, Endocr. 55, 591597.

LincolN, G.A. (1974) Reproduction and "March madness" in the brown hare, Lepus europaeus. $J$. Zool., Lond. 174, 1-14.

Lincoln, G.A. \& MacKinnon, P. (1976) A study of seasonally delayed puberty in the male hare, Lepus europaeus. J. Reprod. Fert. 46, 123-128.

Lyman, C.P. (1943) Control of coat colour in the varying hare, Lepus americana. Bull. Mus. comp. Zool. Harv. 93, 393-461.

MILlAR, R.P. (1972) Reproduction in the rock hyrax (Procavia capensis) with special reference to seasonal 
activity in the male. Ph.D. thesis, University of Liverpool.

Mogler, R.K.H. (1958) Das endokrine System des Syrischen Goldhamsters under Berucksichtigung des naturlichen und experimentellen Winterschlafs. Z. Morph. Oekol. Tiere 47, 267-308.

Pevet, P. \& Saboureau, M. (1973) L'epiphyse du Herisson (Erinaceus europaeus L.) mâle. Z. Zellforsch. mikrosk. Anat. 143, 367-385.

QUAY, W.B. (1956) Volumetric and cytological variation in the pineal body of Peromyscus leucopus (Rodentia) with respect to sex, captivity and daylength. $J$. Morph. 98, 471-491.

ReIter, R.J. (1973) Pineal control of a seasonal reproductive rhythm in male golden hamsters exposed to natural daylight and temperature. Endocrinology $92,423-430$.
Roth, W.D., Wurtman, R.J. \& Altschule, M.D. (1962) Morphologic changes in the pineal parenchyma cells of rats exposed to continuous light or darkness. Endocrinology 71, 888-892.

Rowe, P.H., Lincoln, G.A., Racey, P.A., Lehane, J., Stephenson, M.J., Shenton, J.C. \& Glover, T.D. (1974) Temporal variations of testosterone levels in the peripheral blood plasma of men. $J$. Endocr. 61, 63-73.

VAughan, M.K., Reiter, R.J., VAughan, G.M., Bigelow, L. \& Altschule, M.D. (1972) Inhibition of compensatory ovarian hypertrophy in the mouse and vole: a comparison of Altschule's pineal extract, pineal indoles, vasopressin and oxytocin. Gen. comp. Endocr. 18, 372-377.

Wurtman, R.J., Axelrod, J. \& Kelly, D.E. (1968) The Pineal. Academic Press, New York.

Received 29 September 1975 